\title{
On Some Aspects of Digestion in Ciliary Feeding Animals.
}

\author{
By \\ C. M. Yonge, D.Sc., \\ University of Bristol.
}

THIs paper embodies various observations which were made from time to time while the author was a member of the staff of the Plymouth Laboratory. It also outlines certain generalisations based on the author's previous published work and that of other recent workers in the field of comparative physiology of feeding and digestion.

Animals which obtain their food by means of ciliary mechanisms are characterised, amongst other things, by (1) a great admixture of mucus with the food, (2) continuous feeding within certain limits of temperature, (3) the almost complete absence of muscle from the gut and so of peristalsis and (4) the possession of firm fæces. It is with these points, in particular, that this paper is concerned.

\section{The Rôle of Mucus in Feeding.}

Mucous glands are invariably associated with cilia. In animals which have, as a result of evolutionary processes, to a large extent lost ciliary feeding mechanisms, present in their ancestors, mucous glands are correspondingly reduced in numbers. This is particularly well shown in the Septibranchs (Yonge, 1928). . It has been stated by Nicol (1930) that mucus is particularly concerned with the rejection of large particles and plays little, if any, part in the true feeding process. This view cannot be accepted. There are, it is true, a greater number of mucous glands in rejection tracts of cilia but this can be correlated with the larger particles dealt with. The examination of stomach contents in Lamellibranchs and in Tunicates, such as Phallusia, reveals the presence of mucous strings containing food. Orton (1923) speaks of mucous strings in the stomach of Ostrea as being wound round the revolving head of the style "like a capstan."

The question arises, by what means is the mechanical obstruction presented to digestion by the mucus, which encloses the food, overcome? Orton (1922) suggested that the mucus was digested in Lamellibranchs 
by an enzyme present in the style. There is abundant evidence (summarised by Yonge, 1930) that there is no protease in the gut of Lamellibranchs, food containing protein being ingested by the wandering phagocytes and, if small enough, in the cells of the digestive diverticula. Nelson (1933) has recently reopened this question by suggesting that the chitinous covering of planktonic Crustacea and the cuticle of Nematodes is disintegrated in the stomach of oysters by enzymes from the style. To test the truth of this statement an extract was made of the styles of 20 Mya arenaria (total weight 4 grams) and experiments, with controls, were run for three weeks on portions of the uncalcified chitin of Homarus and of the cuticle of Ascaris. In neither case was any trace of digestion observed.

The solution to the problem appears to lie in the $\mathrm{pH}$ of the medium. Mucus is an amphoteric protein the viscosity of which alters with the hydrogen ion concentration of the medium. Mills (1931) carried out viscosity determinations on the mucus from the mouth cavity of Helix aspersa and found that there was a well-marked maximum at $\mathrm{pH} 8 \cdot 0$. It is impossible to obtain sufficient mucus from any ciliary feeding mechanism for viscosity determinations. All that can be done is to obtain mucous strands by the application of fine, clean sand and then determine the iso-electric point of the mucus by the colorimetric method of Loeb (1922). The results of a series of such determinations, together with the hydrogen ion concentration in the stomach of the animals concerned, are given in Table I.

\section{TABLE I.}

Animal.

Ostrea edulis

Mytilus edulis

Pecten maximus

Phallusia mammillata

Metridium senile
Iso-electric
point of mucus.

ca. $6 \cdot 0$

$6 \cdot 3$

$5-6$

$5 \cdot 6$

$6 \cdot 4$
$\mathrm{pH}$ of stomach fluid.

$5 \cdot 5$

$6 \cdot 1$

$5 \cdot 6$

$5 \cdot 4$

$6 \cdot 7$

It will be seen that in all cases, although the animals belong to three widely different phyla having only ciliary feeding mechanisms as common characters, there is a close agreement between the iso-electric point of the mucus and the hydrogen ion concentration in the stomach. Since the colloidal properties of a protein are at the minimum at the iso-electric point, it follows that viscosity should be lowest here.* The mucus which

* Orton's statement (1922) that the style assists in the dissolution of mucus actually confirms this because it is the acid nature of the style substance which is responsible for the low $\mathrm{pH}$ in the stomach of Lamellibranchs (Yonge, 1925, b, 1926). 
enters the stomach of these animals will therefore be much less viscous than it was in the region where it was secreted-i.e. in the mantle cavity of the Lamellibranchs, the branchial sac of Phallusia and the surface of the disc and tentacles in Metridium. It is not unreasonable to suppose that this lowered viscosity is of significant importance in assisting the digestive processes.

\section{The Nature of the Feeding Processes.}

Unlike the majority of other animals, ciliary feeders do not "take meals" from time to time. So long as environmental conditions, the most important of which is temperature, are suitable they feed continuously and mechanically. Since food is continually being passed into the gut, it follows that digestion also must be a continuous process. The implications of this have not always been realised. In animals where food is, taken in bulk at definite times, the secretion of digestive enzymes is intermittent. There may be a regular rhythm of secretion as there is in Helix (Krijgsman, 1925) and in Astacus (Hirsch \& Jacobs, 1928), or secretion may occur in response to stimulation associated with the presence of food in the gut, as in the Vertebrates.

There is, unfortunately, no evidence about the periodicity of secretion in ciliary feeders, apart from the Lamellibranchs. Here the style supplies the only extracellular enzyme and, as pointed out elsewhere (Yonge, 1932), the style constitutes an ideal mechanism for the continuous liberation of small quantities of enzyme. The enzyme is secreted in the style-sac and is in all probability adsorbed by the protein matrix of the style. The style is being continually and very slowly pushed forward towards the stomach. There the head end is gradually dissolved away owing to the less acid nature of the fluid in that region (Yonge, 1925, b). Even though there be a periodicity in the actual secretion of the enzyme-and on this point there is no evidence-the liberation of the enzyme into the stomach will be continuous. The substance of the style provides an ideal vehicle both for the conveyance and the continuous liberation of the enzyme. It would be interesting to know whether or not there is a periodicity in secretion in the Tunicates, ciliary feeders in which digestion is exclusively extracellular.

Berrill (1929), Graham (1931) and Pantin (1932) have drawn attention. to the importance of duration of enzyme action in connexion with the effect of temperature. The longer the duration the lower will be the apparent optimum temperature. They have correlated their findings with the conditions which exist in the animals studied (the Ascidians, Tethyum pyriforme americanum and Boltenia ovifera, and the Lamellibranch, Pecten maximus) and point out that at all normal temperatures 
the time taken by food to pass through the gut corresponds to the duration of enzyme experiments for which that particular temperature is optimal. These results are of great interest, but it is a little unfortunate that the experiments should all have been carried out on animals with ciliary feeding mechanisms. It is rather questionable whether experiments made with extracts of large numbers of styles or of large quantities of digestive tissues of Ascidians acting on large amounts of substrate have any significant bearing on conditions in animals where a thin but continuous stream of food is subjected to the continous action of minute quantities of enzyme. Moreover, in the case of the Lamellibranchs the time passage through the gut is no indication of the effective duration of enzyme action. The greater part of the time spent in passing through the gut is occupied in the mid- and hind-guts in which, as stated below, no absorption takes place. It is noteworthy that Nicol (1930) was unable to obtain similar results with Sabella pavonina.

\section{Function of the Mid-gut.}

There would seem to be a definite correlation between the length and also the function of the mid-gut and the actual position where the fæces are extruded. This applies also to animals which do not feed by ciliary mechanisms. Graham (1932) has pointed out, with excellent evidence, that the very long coiled gut in Patella vulgaris is probably concerned exclusively with the formation of firm fæces. It is very necessary that an animal which discharges its fæces into the mantle cavity should avoid the fouling which would ensue were these extruded in a loose or particulate condition. Absorption does not take place in the mid-gut of Lamellibranchs and many (possibly all) Gastropods, this region being concerned with the preliminary moulding of the fæces, a slow process in animals where material is moved through the gut by ciliary instead of muscular action.

Absorption does occur in the mid-gut of the Ascidians (Yonge, 1925, a) which is also ciliated and without muscle, but in this case there is no danger of the fæces fouling the collecting mechanism. The mid-gut in this case is very short. In the Septibranchs also (which are exceptions to every rule in the Lamellibranchs) the mid-gut is a straight tube leading directly from the stomach to the hind-gut. But here the collecting mechanism is muscular and not ciliary, and so unlikely to be fouled, and moreover the food consists of large masses and not of finely divided particles which need to be massed together. In the ciliary feeding Annelids such as Sabella, the gut is a straight tube, but the anus is situated at the posterior end, as far removed as possible from the collecting mechanism. 


\section{Formation of F fees.}

The firmness and characteristic shape of the fæcal pellets of a variety of invertebrates has been very well demonstrated by Moore in a series of papers (1931, a, 1931, b, 1932, a, 1932, b). In the Crustacea where the midand hind-guts are very muscular it is not difficult to see how these pellets have been consolidated and moulded. The necessity for a preliminary moulding in the elongated mid-gut of many ciliary feeders has just been commented upon. The final process takes place in the hind-gut. In all animals of this type which the author has studied the hind-gut is characterised by the presence of muscle, especially near the anus, and also by great accumulations of mucous glands. This also appears to be true for Patella and Sabella. If the low pH of the fluid in the stomach is of importance in lowering the viscosity of the mucus, one would expect to find exactly the reverse in the hind-gut where maximum viscosity is needed. This is actually the case. As recorded elsewhere (Yonge, 1925, b, 1926), the $\mathrm{pH}$ in the hind-gut is higher than in any other part of the gut in both Lamellibranchs and Gastropods. In Phallusia where the $\mathrm{pH}$ in the stomach is about $5 \cdot 4$, that of the hind-gut is about $7 \cdot 1$. It appears not unreasonable to assume that this high $\mathrm{pH}$ is of value to these animals by increasing the viscosity of the mucus and thereby assisting in the consolidation of the fæces.

\section{REFERENCES.}

Berrill, N. J. 1929. Digestion in Ascidians and the Influence of Temperature. Brit. J. Exp. Biol., VI, 275-292.

Graham, A. 1931. On the Optimum Hydrogen Ion Concentration and Temperature of the Style Enzyme of Pecten maximus. Proc. Roy. Soc. Lond., B., CVIII, 84-95.

- 1932. On the Structure and Function of the Alimentary Canal of the Limpet. Trans. Roy. Soc. Edin., LVII, 287-308.

Hinsch, G. C. AND JacoBs, W. 1928. Der Arbeitsrhythmus der Mitteldarmdrüse von Astacus leptodactylus. I. Teil. Z. vergl. Physiol., VIII, 102-144.

KriJgsman, B. J. 1925. Arbeitsrhythmus der Verdauungsdrüsen bei Helix pomatia. Z. vergl. Physiol., II, 264-296.

Loeb, J. 1922. Proteins and the Theory of Colloidal Behaviour. New York.

Mrlus, S. M. 1931. The Effect of the H-ion Concentration on Protozoa, as Demonstrated by the Rate of Food Vacuole Formation in Colpidium. J. Exp. Biol., VIII, 17-29. 
Moore, H. B., 1931, a. The Specific Identification of Fæcal Pellets. J. Mar. Biol Assoc., XVII, 359-365.

1931, b. The Systematic Value of a Study of Molluscan Fæces. Proc. Malac. Soc. Lond., XIX, 281-290.

1932, a. The Fæcal Pellets of the Trochidæ. J. Mar: Biol. Assoc., XVIII, 235-242.

1932, b. The Fæcal Pellets of the Anomura. Proc. Roy. Soc. Edin., LII, 296-308.

Nelson, T. C. 1933. On the Digestion of Animal Forms by the Oyster. Proc. Soc. Exp. Biol. Med., XXX, 1287-1290.

Nicol, E. A. T. 1930. The Feeding Mechanism, Formation of the Tube, and Physiology of Digestion in Sabella pavonina. Trans. Roy. Soc. Edin., LVI, 537-598.

Orton, J. H. 1922. Occurrence of a Crystalline Style in the American Slipper Limpet (Crepidula fornicata) and its Allies. Näture, CX, 149. 1923. Fishery Investigations, Series II, 6, No. 3.

Pantin, C. F. A. 1932. Physiological Adaptation. J. Linn. Soc. Lond., Zool., XXXVII, 705-711.

Yonge, C. M. 1925, a. Secretion, Digestion and Assimilation in the Gut of Ciona intestinalis. Brit. J. Exp. Biol., II, 373-388.

1925, b. The Hydrogen Ion Concentration in the Gut of certain Lamellibranchs and Gastropods. J. Mar. Biol. Assoc., XIII, 938-952. 1926. Structure and Physiology of the Organs of Feeding and Digestion in Ostrea edulis. J. Mar. Biol. Assoc., XIV, 295-386.

1928. Structure and Function of the Organs of Feeding and Digestion in the Septibranchs, Cuspidaria and Poromya. Phil. Trans. Roy. Soc. London., B, CCXVI, 221-263.

1930. The Crystalline Style of the Mollusca and a Carnivorous Habit cannot normally Co-exist. Nature, CXXV, 444-445.

1932. Notes on Feeding and Digestion in Pterocera and Vermetus, with a Discussion on the Occurrence of the Crystalline Style in the Gastropoda. Sci. Rpts. Great Barrier Reef Exped., 1928-29, Brit. Mus. (Nat. Hist.), I, 259-281. 